\title{
Application of Modern Security Devices in Senior Secondary Schools: A Tool for Addressing Safety Schools Management under Insurgency
}

\author{
Ibrahim Mohammed1, Mohammed Goni Isa² \\ ${ }^{1}$ School of Education, Department of Primary Education, ${ }^{2}$ Department of History \\ 1,2Umar Suleiman College of Education Gashua, Yobe State, Nigeria
}

\begin{abstract}
This article focused attention on the application of modern security devices in senior secondary schools, as a strategy for reducing insurgent attacks in educational institutions in Nigeria. The study gave reference to the Northeast, where the Jama'atul Ahlil Sunnah Lidda'awati Wal Jihad popularly known as Boko Haram are terrorizing the population, destruction of school buildings and sometimes abduction of school students especially female students. Learning environments need constant protection from both internal and external threats to avoid loss of lives and properties. A safe school environment is free from physical or psychological harm. Therefore, the article emphasized the need to apply modern security devices, such as Closed Circuit Television, Scan Cards, Buzzer System, Surveillance Camera, Tracking Device, Intercom, and Computer, among others. These should be part of schools' operation in order to reduce the rate of attacks and delay the actions intended by the insurgents. The paper also highlighted the factors determining school location, types of security devices needed were also discussed, guiding principles in planning safe schools, and challenges to the planning. It also recommended that government should increase the allocation of funds in education sector, to enable the provision of security gadgets, constant training and regular supervision to ensure the conditions of these devices for safety and educational development. The article concludes that, modern security devices are neglected in most of Nigerian educational institutions of learning especially in Northeastern State where Boko Haram engaged in killing students, destroying schools and abduction of school students.
\end{abstract}

Keywords: Insurgency, Nigeria, Schools, Security devices

\section{INTRODUCTION}

Many secondary schools are lacking modern security devices in their effort to enhance safety of the schools' populationsstudents, teachers and visitors. This has exacerbated the security challenges faced by various educational institutions as more people are victimized by violent crimes. In the face of the current spate of insurgency in Nigeria, the need for more security gadgets is intense given the obvious tendency of the insurgents to target schools in many occasions. School is a system that requires human and material resources, modern security devices among other thing for proper goal attainment and for expected planned result. Therefore school system requires plans ranging from education needs, site location, location of structures, facilities, management of facilities, Security and other factors that may affect the afore mentioned. A secure learning environment provides protection from threat, danger, injuries or loss. A safe school environment is free from physical or psychological harm (INEE 2012).

There is need for schools to adopt policies and security measures to combat modern threats in an effort to reduce the risk of insecurity in schools especially during BokoHaram insurgency that normally affects many secondary schools in northern Nigeria with specific references to Northeastern Nigeria. Installations of modern security devices, security software and technologies in schools will reduce insecurity and it leads to comprehensive safety and security plan. However, based on the above statement, Jumare (2016), posit that for avoidance of wastages of human and non-human materials as well as time resources, education managers and planners need to be acquaint themselves with modern knowledge, practice and operation of modern security devices that are related to school plant planning and it is related activities. This knowledge will help the school plant planners and managers especially in the present day where there is over enrolment of students population, casual attack and abduction of students are happening especially in North eastern part of Nigeria.

Therefore, in Nigeria, with special focus to Northeastern States, government should be committed in improving safety and healthy learning environment where students and staff will be secure in their pursuit of educational success. But, there are some areas that government needs to pay much attention in making schools safe from internal violence and external attacks by the terrorists group especially the one we are experiencing presently in Nigeria. Ruwa (2013) asserted that these are the reasons government spent greater part in 2012 and 2013 National Budget on Security. Manga (2015) beliefs that safety and security of staff and students in various schools in west Africa is not negotiable, this is because no effective teaching and learning can take place in a state of insecurity, in fact school buildings, infrastructures, staff and students have become target of bombings and other forms of destruction by terrorism and criminals.

In view of this background, the present study will investigate the application of modern security devices in senior secondary schools as a tool for addressing safety schools management under insurgency.

\section{Definition of Concepts}

Isaac and Musibau (2010), sees school plant as a process in which a suitable site is selected and instructional space, 
administrative space, curriculum space and space of convenience are designed to facilitate teaching and learning process in the school system. School Plant is the process of designing and erecting buildings, making roads, bridges, drainages, landscaping and other structures in a school environment and school planning embraces the school site, school building in terms of class rooms, laboratories, workshops, libraries, playgrounds, furniture, as well as infrastructures which include road network, electricity and water supply (Sani,2007)

School Safety refers to measures that are put in place in the planning of school facilities so as to protect staff and students from sustaining unnecessary injuries as they interact with school facilities. Therefore, school security on the other hand refers to measures that are embedded in planning of school facilities aimed at preventing and protecting the school from harmful, aggressive and dangerous external influences. Even though safety and security are closely interrelated, one may look at safety as internal issues in school and security can be view as external issues which involve protection from deliberate attacks, dangerous actions which perpetrated by external source such as Boko-Haram that cause harm and even loss of lives and property. Security issues that affect schools include shooting, bombing, threats, kidnapping, abduction of students, vandalism, raping among others (Manga, 2015)

\section{Importance of School Safety}

Researchers have shown that the importance of school safety cannot be over emphasized. Thus, school safety serves as a basis for any other program or activity to achieve school goals. Udosen (2015) asserted that the following are some of the importance of school safety:

$>$ It improves students' performance: This implies that, school with standard safety arrangement devoid from noise and hazard connected with security devices and safety tend to perform better than those without.

$>$ It improves students' school attendance: School with good plant in terms of safety and security, with beautiful environment or flowers and adequate recreational facilities attract students to attend school. This means that school without such facilities may be hostile to students especially in a state of insecurity.

$>$ It improves students attitude to learning: Safety school plant create friendly environment for learning, this eases to motivate both students and teachers to learn. Therefore, position of relevant facilities aid learning within classroom and around the school.

\section{School Planning and Location}

Ibitoye (as cited in Manga 2012) viewed school planning and location simply means schools mapping which involves a systematic process of identifying the most advantageous site where schools are to be situated. It involves choosing a most favorable environment that will be accessible to the learners by ensuring that the learners does not have to walk long distance to get to nearest schools, it also determining the future location of school so as to ensure equitable distribution of school and educational facilities in a given state or geographical location.

\section{Factors Determining School Planning and Location}

$>$ Centrality: This means school should be located in a central position within the locality in order to ensure from all directions within the catchment area, because children in primary school do not walk more than four (4) kilometers and those in secondary schools do not walk more than six (6) kilometers.

$>$ Population Concentration: School should be located where the population is more concentrated.

$>$ Safety: School should be located in an area that is safe with special focus to the followings:

$>$ Traffic hazard: school should be far away from busy highway and railway crossing in order to minimize the risk.

$>$ Industrial pollution: School should not be located in an industrial area because of the poisonous substances in the air and dumping industrial waste in the water near a school.

$>$ Topographical hazards: School should not be located in a rocky hill in order to prevent students from sustaining injuries and falling down on a sharp stone, and school should not be located in a swampy area so that mosquitoes, flies and other dangerous insects could not bite student or transmit any diseases.

$>$ Drainage consideration: From different angle such as:

$>$ Rate of drainage

$>$ Availability of water

$>$ Security: The security of proposed site should be considered in order to maintain the low and order.

Health Services: Community should provide health care centre such as hospital, clinic, dispensary so that staff and students can patronize time to time because health is power and is wealth.

Commercial services, banking services and communication network are also important in school planning and location.

\section{Security Devices Needed For Planning Safe Schools}

Chiaha and Mbanefor (2013) in Manga (2015), asserted that when an appropriate site is selected, it is appropriate to start by erecting a concrete fence around the perimeter of the school. This will help in establishing school boundaries as well as arrest future incursion to the school land by members of the immediate community. A high solid wall with spikes or barbed wire any other sharp object at the top of the wall. This will discourage those who might wish to jump or climb the school fence for the purpose of destroying school. Therefore, apart from single entry at the gate, there is need for security room at the main entrance to serve as shelter for security men on duty as well as store for them to keep their security gadgets required for security duties. However, provision should be made for central security office in the school with all security devices such as:

\section{$>$ Closed Circuit Television (CCTV):}

The CCTV is an electronic device that is applied to provide surveillance to an area in the school that are not directly watch by staff, remote areas that are prune to vandalization during or after school hours.

\section{$>$ Global System Mobile (GSM):}

Global System Mobile can be apply to make emergency calls to security personnel and text messages quietly to them and to record criminal actions either by audio or video means.

\section{Scan Cards:}

This Scand Cards are relatively new to school community, because they are highly sensitive and are easily to be lost or stolen. The stranger and effectiveness of the Scand Cards as a security device depend on the size of the school. The bigger 
the Scand Cards the bigger the school, the smaller the Scand Cards the smaller the school.

\section{$>$ Buzzer System:}

This is the most common type of security devices, which are used in many standard organizations for security alarms. Schools also can make use of it because buzzer system devices are mostly installed at entry point such as doorways, corridors, receptions, halls as well as common room. It can be used to reduce the level of risks for safety of staff and students, school facilities as well as community members

\section{$>$ Tracking Devices:}

These are devices that are used to in determining the location of a person or object and what is happening to them. Tracking devices are in various models. These include Global Positioning System (GPS) and Child Locator (CL). The GPS tracking devices is use in school environment to capture the position of person or object and the current situation of school environment, and it help in locating the position of a child even in a crowded places.

\section{$>$ Computer:}

Computer can be made available in school while planning for safety of student's records, school administrative actions, storing staff and student biometric information. It can also use for e-research, keeping examination results as a way of safety in school.

\section{$>$ Surveillance Cameras:}

Surveillance camera assist in tracking happening in and around the school environment, it can apply in improving safety in school because it survey the school compound and enable management and school security personals to know what is happening in school whether it is dangerous that required more security agents or not

\section{Tasers:}

This is another security devices that make a person to feel a small electronics shock and become unconscious temporary and will not allowed that person to move for a short time. The temporary incapacitation gives an opportunity to rush and arrest the criminals or any group of militants or take other actions or measure. It can be apply to schools in terms of security of students, staff and schools administrators as well as school buildings. Since they are not allowed to use sophisticated weapons in schools.

\section{$>$ Intercom system:}

- These security devices is of different types, but the prominent ones is the telephone intercom device, it communicate audio messages only between one office and another office in an organization. The other one is video intercom which helps in identifying any person who rings at the door either in the office or at home. This device can make you to decide whether to open the door or not and at the same time gives you an opportunity to call for help when the situation become uncontrolled or need extra-hands.

\section{- Whistles:}

This is the most simple and affordable security device that can be use in schools for student's safety. This is because security men can blow whistles to serve as an alert in an emergency situation. Both staff and students can be noted whenever whistle is blowing in the school and they could take necessary actions before any bad things happen to them.

\section{Need for Safe School}

Students cannot be able to succeed academically if they don't feel safe and secured in school. No teachers will teach effectively and efficiently if there is not adequate security in the school and therefore, there is a plan in place to ensure the school is well prepared for an emergency. Specifically, the Police, State Security Services, other Intelligent Agencies, such as: Military, Immigration, Civil Defense Corps and Prison Services are directly shouldered with these responsibilities (Ibrahim, 2002). Staff and students need to be safe in school and feel physically and psychologically from an incident is a critical task requiring at least as much skill and training for restoring the building and infrastructure. There is need for true support for people healing from trauma involves the understanding of some basic principle of trauma recovery. (Nasp, 2013)

Trauma intervention is an area of expertise. The strategies for helping children heal from trauma may not be same as helping students coped with other emotional issues. Not all mental health professional are trained to treat trauma patients. When it is done partly, crisis exposure, generate self fulfilling prophesies or reduce perceptions of independent problem solving. (Nasp, 2013).When students are on school buses, whether they are travelling to or from school or out on field trips, the school is responsible for these students adequate security. Schools need to have plan in place for how to handle bus accident or buses off campus with students needs to coordinate with the transport company to ensure that buses drivers are monitor regularly and participate in training and drills. For example, bus drivers can be trained on such topics as evacuating young passengers. Students' bus riders need to received instruction and practice in bus evacuation from time to time each year.

\section{Principles Needed in Planning Safe Schools}

A school committee of expertise should be formulated for the prevention of internal violence and management of risk. For schools to success in safe schools planning the following principles should be considered.

$>$ Plans should be clearly define roles and responsibilities. It is important that all key people should now their roles and responsibilities as well as the roles and responsibilities of others in the events of a crisis situation. Plans should also include contingency provision to enable implementation a success when key individuals are unavailable or not in a position to perform their roles.

$>$ Plans should be coordinated with non public schools and recognize the needs of special school population. Students and staff with disabilities, limited English speaking students and other special students populations should be addressed in all plans.

$>$ Plans should be continually reviewed and updated to remain current, changes in personnel, local conditions and other factors necessitate periodic review and updating of plans to ensure their applicability to current conditions.

$>$ Planning should be comprehensive, on compassing activities from early prevention through crisis response. In addressing the intent of the law schools should focus on a process driven approach to planning rather than on a checklist of activities that must be done. 
$>$ Planning should be user-friendly, easy to read and understandable. The plan should be widely disseminated within the community to foster broad acceptance and participation.

$>$ Leadership is needed throughout the planning process. School and community leadership needs to be continuously provided to build and maintained the momentum for effective planning.

$>$ Effective planning takes time; the planning process must include adequate time in order to ensure broad participation and active involvement of key partners in the development of plans. (Albany, 2001)

\section{Challenges in Applying Modern Security Device in Safe Schools Planning}

The following are some of the current challenges facing educational institutions in Nigeria especially Northeastern part of where abduction of school students, Kidnapping of innocent people, bombing, destroying of school buildings become the order of the day. These include:

$>$ Insufficient modern security devices in educational institutions.

$>$ There is need for more funds to education sector for regular maintenance.

$>$ Lack of professionals and experts security men for installation, operations as well as management of these devices.

$>$ Lack of regular Supervision to check the security men on duties and inspect these devices whether they are in other or not and to report to the appropriate authority.

\section{Recommendations:}

Based on the challenges raised above on the application of modern security devices in educational institutions in Nigeria, the following recommendations are hereby made:

$>$ Government should ensure that modern security devices should be considered while planning schools in order to minimize the frequent attacks of school and to deter terrorists and criminals.

$>$ Government should increase financial allocation to education sector, this is because these security devices are highly expensive, and therefore, sufficient funds are needed for the purpose of purchasing and maintenance.

$>$ There is need for government to employ professional and experts security men who can install, operate as well as managing these devices. So also, the current security men on ground need to go for further training and retraining in order to acquire modern security techniques, strategies and operation, government should liaised or partner with professional body in managing security devices and their applications.

$>$ There should be professional supervisory team who can regularly supervise and check the conditions of these devices and advice these men on duties as well as write report to the appropriate authorities for further actions.

\section{Conclusion}

The paper concluded that, modern security devices in planning safe schools in Nigeria has almost neglected especially in the northeastern part where abduction and killing of school students and staff become order of the day.
This shows that there is need for government to rethink on how locate and relocate schools in Nigeria and to ensure that these security devices are fixed in almost all schools for the safety of students, teachers and school administrators for effective teaching, learning and management of schools for better educational development.

\section{References}

[1] Albany, N.Y. (2001), Planning safe schools for future. New York State Educational Department

[2] Chiaha, G.T.U. \& Mbanefo, M.C. (2013), Managing education for personal safety and security in Nigerian Schools. Ibadan His Lineage publishing

[3] Ibrahim, J. (2002). "Preface" in E.O.E Alemika and Festus Okoye (eds.) Ethno-Religious conflicts and democracy in Nigeria. Kaduna: Human Right Monitor.

[4] International Network for Education in Emergency (2012). Minimum Standards for Education. Preparedness, response, recovery. Creatrix Design Group. Canada

[5] Isaac, A. A. and Musibau, A.Y. (2016), School plant planning and students' learning outcomes in south west Nigerian secondary schools. International Journal of Science education, 2(1), 47-53

[6] Jumare, A. M. (2016), introduction to issues in education management in Nigeria, Ahmadu Bello University Press Limited, Zaria, Kaduna State, Nigeria

[7] Manga, S. D. (2015) safety and security consideration in school plant construction in West Africa: Implication for research and Development. A paper presented during the tenth international conference on research and development, held at Sale Audio Visuelle University of Aborney Calavi, Cotonou, Republic of Benin on the theme: Research for Sustainable Development: Strategies and procedures for Developing Nation from may 12:13

[8] Manga, S.D. (2012), introduction to educational management, Usmanu Danfodiyo University press, Sokoto, Nigeria.

[9] National Association of School Psychologists, (2013), A frame work for safe and successful school. www.nasponline.org. Retrieved on May 2018

[10] Ruwa, M. (2013). Education for peaceful co-existence. What is wrong with the linkage in Nigeria? A paper presented at the $33^{\text {rd }}$ Annual International Conference of philosophy of Education Association of Nigeria (PEAN) held at University of Ibadan, October $21^{\text {st }}-25$, 2013

[11] Sani, D, M. (2007), Relationship among school plant construction, utilization, maintenance and school effectiveness in Kebbi State secondary schools, Nigeria Unpublished PhD Thesis, University of Ilorin, Nigeria.

[12] Udosen, N.P. (2015), Importance of school safety to teaching learning process. Retrieved from https://amse.wardress.com on 08-10-2017 